\title{
EDUCATION TECHNOLOGY AND ANOTHER PROBLEM OF TODAY'S EDUCATION SYSTEM IN ALBANIA
}

\author{
Menada Petro ${ }^{1}$ \\ Rita Loloçi ${ }^{2}$ \\ 1“Aleksandër Moisiu” University; Faculty of Education; Durrës, Albania menada_petro@yahoo.com \\ 2“Aleksandër Moisiu” University; Faculty of Education; Durrës, Albania ritaloloci@ gmail.com
}

\begin{abstract}
The rapid development of society has also influenced in the development of the education system. The school has undergone a change in system and structure, in programs and ideas. The scientific material that is offered and the pedagogic staff are the two solid pillars without which the school cannot stand. But the rapid development of technology and leaving aside the textbooks, the development and the importance of integrating contemporary methodologies, the spread of the online systems and the wide spread of internet usage and technological devices, have highlighted the need to resize these two important pillars. Also, the development of technology in education, the creation of new digital and effective platforms in the delivery of teaching, have found the pedagogical school staff unprepared and their knowledge acquired during their studies or their experiences are aging at the same speed, highlighting the inability to match teachers' ICT competencies with those of students.

Meanwhile, in July 2018, Ministry of Education (MASR) decided to ban the use of mobile phones during the lessons in the schools all around the country. This decision was accompanied with many debates and objections. The modern teaching methodologies aim at raising the creativity, encouraging the innovations, independent and critical thinking.

Covid-19 brought to the forefront the teaching through technologies and the most used device was the mobile phone. From this point of view, besides the picture of the present situation, teacher's knowledge and needs in Durres Region, related to the use of technology in the teaching process, this paper is a critical view towards these two lines, on one side the decision taken by the Ministry, and on the other side the teaching with modern methods, are these two parallel lines or do they exclude each other

In conclusion, this paper gives recommendations for a modern teaching and for the possibility to use technological gadgets, including mobiles or iPads, in order to have a more effective, attractive and comprehensive teaching process.
\end{abstract}

Key words: education; contemporary methods; technology; digital programmes; online system. Paper field: Education

\section{INTRODUCTION}

Just like in all the country, even in the Durres Region the preuniversity education system is based on the Albanian education tradition, functions in accordance with the Constitution of The Albanian Republic, Albanian Legislation and it is developed in accordance with the common values of the contemporary education systems and it aims at the formation of each individual in order to face the future challenges, to be responsible for the family, the society and for the country.

Since Durres is the second biggest city in terms of population and of geographical area, it has a considerable number of public and non public schools. In the public sector there are 11 kindergardens and 73 junior high schools and high schools. There are 56 schools junior high from which 36 are located in the villages, 17 high schools from which 8 in the villages. From the high schools 4 are joined, 1 is sportive high schools, 1 is vocational high school and 1 is technological high school. While in the non public sector there are 2 kindrgardens and 19 junior high and high schools, from which 2 are junior high and the others are 12 joined high schools and 3 comprehensive high schools. Since the schools that are located closer to the city center have a better opportunity and access in portals and more training options, for this papeer, it was thought as more fruitful taking data and information for the needs by the pedagogical staff of suburbs and villages, thus there were chosen junior high schools and high schools, vocational and comprehensive high schools. 
The schools that will be taken in analysis are thought to be in the public sector. In total, in this analysis are included 10 schools, 2 of which are junior high and 8 high schools, 2 of which are vocational high school, 1 artistic and 4 comprehensive. In each of these schools were randomly chosen 18-19 teachers to complete the questionnaries. From the chosen target group were 171 teachers, 14 headmasters, 124 of which were females and 74 males that were inclujded in the analysis.

From the analysis, it has resulted that the selected group uses more Facebook (132) and Google (93) and less the other networks. The majority of them did not like to share their professional experiences in these networks. It resulted by the questionnaries that the chosen group uses technological means and the most used is the laptop or the computer (153). Only 9 of them answered that they used other means of technology.

\section{NEEDS ANALYSIS}

Although facts coming from researches show that the teacher's development has a valuable impact on the student and his achievements and it is considered as an essential mechanism in the school reform (Darling-Hammond et al, 1999), effective practices of development have failed to materialize for the majority of teachers, schools and districts.

From the questionnaires, it has resulted that $156(84,3 \%)$ teachers consider themselves well prepared with the knowledge they have acquired in the university, and only 5 of them said that they are not well prepared in the university related to the work challenges and 24 teachers did not respond to this question.

In relation to the gap the teachers percept between the acquired competencies in the university and those required in the job market, the majority of them think that it is exactly in the lack of approaches of cross-professional competence development, and also in the lack of the ability to match the ICT teacher competencies with the technology of the new generation of students, in the same way the lack of practical application of the appropriate education theory during their university studies, also the lack of student guidance and career counselling.

$\begin{array}{lr}\text { Shortcomings } & 57 \\ \text { Lack of approaches to developing cross-occupational competencies } & 42 \\ \text { Lack of ability to match teacher ICT competencies } & 39 \\ \text { Lack of application of relevant educational theory in practice } & 30 \\ \text { Lack of student career guidance and counseling } & 23 \\ \text { Lack of ability to identify what does the student need } & 18 \\ \text { Lack of possibility to identify job demand } & 6 \\ \text { Other } & 39 \\ \text { No answer }\end{array}$

The main incentives to enrol in Continuous Professional Development are: the need for creating effective teaching and learning environments ( 75 teachers), to help pupils develop better their competences (66 teachers), to develop ICT teaching skills (63 teachers), to make the school practice more efficient (63), improvement of self-knowledge (63), the need for the specific knowledge in everyday work (60), formal need for the professional career (54), to make the curricula more attractive (45), to help pupils to better use their learning time (45), to learn about practices from around the world (36), to provide an environment for developing new and innovative solutions (27), etc.

As it can be seen in the following table the majority of teachers do not have any knowledge about computer programs. Only a few of them have knowledge and only very few use them. 
ISSN 2661-2666 (Online) International Scientific Journal Monte (ISJM) DOI: 10.33807/monte.20211902

Volume 4, (No).2 (2021): April

\begin{tabular}{|c|c|c|c|c|c|c|c|c|c|}
\hline & Moodle & Mahara & Prezi & Kahoot & Padlet & $\begin{array}{l}\text { OneNote } \\
\text { Notebook }\end{array}$ & Socrative & $\begin{array}{l}\text { Google } \\
\text { Forms }\end{array}$ & $\begin{array}{l}\text { Google } \\
\text { Classroom }\end{array}$ \\
\hline $\begin{array}{l}\text { I don't } \\
\text { know }\end{array}$ & 131 & 171 & 100 & 145 & 163 & 170 & 148 & 166 & 123 \\
\hline I know & 13 & & 60 & 1 & & 10 & 8 & 13 & 25 \\
\hline $\begin{array}{l}\text { I use } \\
\text { personally }\end{array}$ & 1 & 1 & 2 & & 1 & 4 & & 4 & 5 \\
\hline $\begin{array}{l}\text { I use for } \\
\text { teaching }\end{array}$ & 1 & & 4 & & & & 1 & 2 & 3 \\
\hline No answer & 39 & 13 & 19 & 39 & 21 & 1 & 28 & & 29 \\
\hline
\end{tabular}

Actual situation in schools and also teachers needs for using ICT in the teaching process.

\begin{tabular}{|c|c|c|c|}
\hline & Yes & No & $\begin{array}{l}\text { No } \\
\text { answer }\end{array}$ \\
\hline My employer has provided me with ICT equipment that meets my needs & 86 & 99 & \\
\hline I receive sufficient technical support with sufficient speed for ICT use at my school & 88 & 97 & \\
\hline $\begin{array}{l}\text { Does your school have a wireless network that is also accessible to students and } \\
\text { visitors on their own devices? }\end{array}$ & 92 & 92 & 1 \\
\hline $\begin{array}{l}\text { Does your school have a pedagogical support person available to help with using } \\
\text { ICT in education? }\end{array}$ & 140 & 45 & \\
\hline I know how to utilize digital teaching materials in my teaching & 157 & 28 & \\
\hline It is hard for me to find high-quality digital materials for the topics being taught & 36 & 145 & 4 \\
\hline I am familiar with the principles of using Creative Commons licenses. & 132 & 50 & 3 \\
\hline I find good ways to utilize ICT in various learning situations. & 149 & 35 & 1 \\
\hline $\begin{array}{l}\text { It is easy to make use of information and communications technology (ICT) } \\
\text { according to the curriculum }\end{array}$ & 146 & 32 & 7 \\
\hline $\begin{array}{l}\text { I know that I need to enhance my digital skills, but I am unsure how and where to } \\
\text { start }\end{array}$ & 131 & 52 & 2 \\
\hline $\begin{array}{l}\text { I actively seek out best practices, courses or other advice to improve my own digital } \\
\text { pedagogies and wider digital competences }\end{array}$ & 150 & 35 & \\
\hline I only rarely, if at all, use the internet to update my knowledge or skills & 39 & 145 & 1 \\
\hline
\end{tabular}

From open questions the teachers have added that it is also important for them to train on the use of ICT in teaching (57 teachers), new and contemporary methods (48 teachers), the most accurate and effective way of drafting the tests (26), acquaintance with new curricula (21), successful implementation of the teaching hours (19), fulfilment of portfolio tasks (15), and a better infrastructure (8).

\section{BANNING THE MOBILE PHONES IN SCHOOLS - THE EFFECTIVENESS AND THE OBJECTIONS}

While the teachers express their need for trainings in the development of ICT skills, and also the matching of their abilities with the student's abilities, they express the lack of technological infrastructure and when at the same time in the developed countries the teaching process is done using educational technological programs such as Moodle, Doodle, Google Form, Kahoot, etc. easily downloadable in mobiles, MASR issues the Order no. 493 for the prohibition of the mobiles phones during the teaching process for the teachers and students. (MASR 2018).

Three months later it issues Direction 34 for its application (MASR 2018), according to which for those who will get caught using the mobiles, there will be measures taken from schools and students may even be expelled from schools while teachers may be suspended. Meanwhile the mobile phones with be taken to the police by the responsible structures prescribed in the Direction. In order to take this decision there were no studies carried or any evaluation, teachers or students opinion was not taken in consideration and it was advertised as a novelty and a direction that will improve the teaching quality and the students results.

By issuing and applying such a direction, we have accepted that the pedagogical staff in schools are unable to make student use the only possible technology they have and which is not bought with public funds, in order to improve the teaching process generally speaking, if we take in consideration that students are more attracted by the use of their mobile than by the narrative listening of their teacher.

At the same time we have lost the battle to prepare students for the future and we are keeping them hostage of the past. 
To measure the effectiveness and applicability of this Order, 500 students and 200 teachers from different schools were randomly selected.

The gathered data during the study show that from the 500 contacted students. $90 \%$ use the latest mobiles (20152019 ) and only $10 \%$ use older mobiles. 50\% of them have a Samsung and $40 \%$ an Iphone. $74 \%$ say that they do not give it to the teachers but tell them they have left them at home, while they secretly use them. $26 \%$ have two mobiles and keep one and give the other.

It has resulted that 93\% did not have an improvement in their school results, and they even say they talk more to each other, since their attention is the same. Students say that in those classes that the teacher makes the teaching interesting they follow him with pleasure no matter if they have or not their mobiles, and when they consider the classes boring even though they cannot use their mobiles they will be focused in other things, daydreaming or will be speaking to their friends. When it comes to teachers using their phones, $99 \%$ of students say that teachers do not use them during the class period and $30 \%$ say that they use mobiles only during recess time, since the teachers explain I the same way as before.

The same questions were addressed to 200 teachers who said that $70 \%$ of them have the latest mobiles (2015-2019) and $30 \%$ have older mobiles. $46 \%$ use Samsung and $24 \%$ use Iphones. $80 \%$ of the teachers give their mobiles in the headmaster office and take them during recces time and $20 \%$ of them use two mobiles. When it comes to the improvement of student's results, $90 \%$ of the teachers say that it does not have any impact, and they even draw student's attention more often now to keep order so they do not quarrel with each other. In relation to the improvement of their teaching, $98 \%$ of them say that id did not have any impact.

The Covid-19 pandemic found the education system unprepared and placed school pedagogical staffs facing the challenge of technology. Suddenly the whole lesson shifted online and the most used device was the phone. While even today (2021) the Order has not been repealed, but by the ministry itself, it is widely accepted that mobile phones should be used during online learning.

Thus from the surveys conducted by MASR (March, 2020), for online teaching it has resulted that $96.8 \%$ of students, $95.3 \%$ of parents and $98.7 \%$ of teachers, have been engaged in online teaching. $77.4 \%$ of parents claim that their children are developing digital competence by applying online learning. $74.1 \%$ of teachers agree that they like interaction in electronic form, even $88.7 \%$ of teachers use video-selfie to determine the teaching contents.

Despite exploring the virtual classroom platforms that teachers are using at the moment $(68.1 \%$ claim to have used different online platforms), WhatsApp remains the most used online communication by teachers, with $96.4 \%$ of them.

$88.5 \%$ of students agree that they actively communicate with classmates and teachers, in the electronic way. $83.6 \%$ of them are able to manage their study time effectively and complete their assignments. $90 \%$ of them are maximally committed to performing the tasks given by teachers, during online learning.

In general, $74 \%$ of teachers and $77.5 \%$ of students agree that they like interaction in electronic form.

Based on survey results (MASR, April 2020), the smartphone is the most widely used device for conducting online lessons. About $95.7 \%$ of students (36.6\% in the village and $59.1 \%$ in the city), $96.8 \%$ of parents (of whom $31.1 \%$ in the village and $65.7 \%$ in the city) and $95.9 \%$ of teachers (of whom $45.8 \%$ in the village and $50.1 \%$ in the city) develop learning at home using a smart phone (mobile).

\section{CONCLUSIONS AND RECOMMENDATIONS}

The results, the above-mentioned data and their interpretation show that the majority of teachers need continuous and sustainable trainings. Among other things teachers have expressed their need for trainings on the use of ICT in the teaching process, in their abilities to match their ICT knowledge with the knowledge of their students and the inclusion of new digital programs in the teaching process.

The need to create an effective teaching process and teaching environment, making the teaching practices more efficient and at the same time a positive work environment, can be achieved by adding funds for the technological infrastructure in the schools, including internet and networks, technological tools and teaching programs installation and the teacher's and student's evaluation without leaving behind the encouragement and the increasing demand of the teachers for acquiring digital teaching programs. We should not forget that our schools are overpopulated and the classrooms have one teacher for 30-40 students, that is why the number of stude4nts should be reduced and there should be more teachers in the classrooms, including the teacher's assistants.

At the same time, in a time when it is impossible to spread the digital network all over the country because or high costs, teachers and students can use their own digital tools, including their Ipads, Laptops and their mobiles in order to improve their teaching process. 
The majority of schools ask from time-to-time funds form the parents for the different needs of the schools, which are often administrative needs, or to help families with special needs. If these funds would be asked to parents in order to buy Ipads, or if support would be asked to the businesses, not only by the schools, but mainly by drafting education policies by the Ministry, and if the use of mobiles would be allowed, not to talk on the phone but for the teaching process, always depending on age and students level, then we would have an improvement of the students' results, pedagogical staff and students would be prepared for this emergency situation, but above all we would have a higher teaching quality.

But in order to achieve all the above mentioned, the problem does not stand neither with the teachers nor with the students, but with the drafting of the supporting education policies of the Ministr5y, the recognition of the real situation and drafting long term strategies and plans for the schools of the future. 


\section{LITERATURE}

ACCE (2015) Raport "Zhvillimi profesional dhe vlerësimi i mësuesve në Shqipëri”

Darling-Hammond, L., Wise, A.E., \& Kline, S. P. (1999). A license to teach: Raising standards for teaching. San Francisco, CA: Jossey-Bass

Filho W. L. F, Misfsund M. M., Shiel C. S., Pretorius R. P. (2016) Handbook of Theory and Practice of Sustainable Development in Higher Education, Volume 3, Springer, USA, ISBN 3319478958, 9783319478951

IZHA (2016) Raport Kombëtar "Identifikimi i nevojave për trajnimin e drejtuesve dhe mësuesve të shkollave në arsimin parauniversitar

IZHA (2016) Standardet profesionale të formimit të përgjithshëm dhe lëndor të mësuesit në arsimin e mesëm të ulët dhe arsimin e mesëm të lartë

MASR (2018) Urdher Nr. 493, Date 30.07.2018 Per Mosperdorimin e Telefonit Celular Gjate Procesit Mesimor ne Shkolla

MASR (2018) Udhezim Nr. 34, Date 16.11.2018 Per Ndalimin e Telefonit Celular ne Institucionet Arsimore Paraunivesritare

MASR \& ASCAP (2020) Sondazhi i Mësimit Online, perceptime të nxënësve, prindërve dhe mësuesve; fq 6 - 57; https://www.ascap.edu.al/wp-content/uploads/2020/03/Sondazhi-i-m\%C3\%ABsimit-online.pdf

MASR \& ASCAP (2020) Sondazhi i Mësimit Online 2, perceptime të nxënësve, prindërve dhe mësuesve; fq 5; https://arsimi.gov.al/wp-content/uploads/2020/04/1586552308063 Sondazhi-i-m\%C3\%ABsimit-online2.pdf

Sterling S. S. (2015) Sustainable Education Re-Visioning Learning and Change, Published by Green Book for the Schumacher Society

Wheeler K. A. \& Bijur A. P. (2000) Education for a Sustainable Future a Paradigm of Hope for the $21^{\text {st }}$ Century, Concord Consortium, Boston, Massachusetts, ISBN 0-306-46420-9

Bashkia. (2018, February 3): http://www.durres.gov.al/bashkia/rajonet/673-profili-i-bashkise-durres

DAR. (2018, February 2): http://dardurres.edu.al/index.php/institucionet-arsimore/191-institucionet-arsimore-jopublike-rrethi-durres 